\title{
Moment aniversar: dr. ing. Nicolae Doniță
}

Anul acesta, pe 20 noiembrie, d-1 dr. Nicolae Doniță a împlinit frumoasa vârstă de 90 ani. Deoarece opera știinţifică este mult mai bine descrisă de sărbătorit, într-un interviu apărut în numărul precedent al Revistei Bucovina Forestieră, am să încep cu unul din cele mai emoționante momente pe care d-1 Doniță a reușit să le creeze, involuntar, la ședința festivă organizată de Secția de silvicultură a Academiei de Științe Agricole și Silvice, două zile mai târziu, pe 22 noiembrie. După ce au fost susţinute cele patru comunicări incluse (cu oarecare parcimonie) de organizatori în program, a urmat cuvântul de mulțumire al sărbătoritului. Scuzându-se că a uitat acasă textul pe care îl pregătise, d-1 Doniță a avut un moment de tăcere, foarte potrivit ca durată, după care a urmat o frază memorabilă, pe care sper să o redau în toată candoarea ei: „Cea mai mare realizare a vieții mele este această nişă socială pe care am reușit să o creez şi în care mă simt foarte bine". Ana Blandiana spunea că poezia este o stare care se naşte între cuvinte...

Dovada calităţii acestei „nişei sociale” este dubla aniversare: cu o săptămână înaintea evenimentului de la București, pe 15 noiembrie, în clădirea Rectoratului USAMVB ,Regele Mihai I al României” din Timisoara, colegi, foști doctoranzi și mai tineri colaboratori de la USAMVB din Timișoara și de la Universitatea Babeș-Bolyai din Cluj-Napoca au organizat o conferință omagială la care au fost prezenți peste 100 de participanţi, din mai multe centre universitare și științifice - Timișoara (USAMVB „Regele Mihai I al României”), Cluj-Napoca (Universitatea Babeș-Bolyai și Institutul de Cercetări Biologice), Brașov (Universitatea Transilvania), Suceava (Universitatea Ștefan

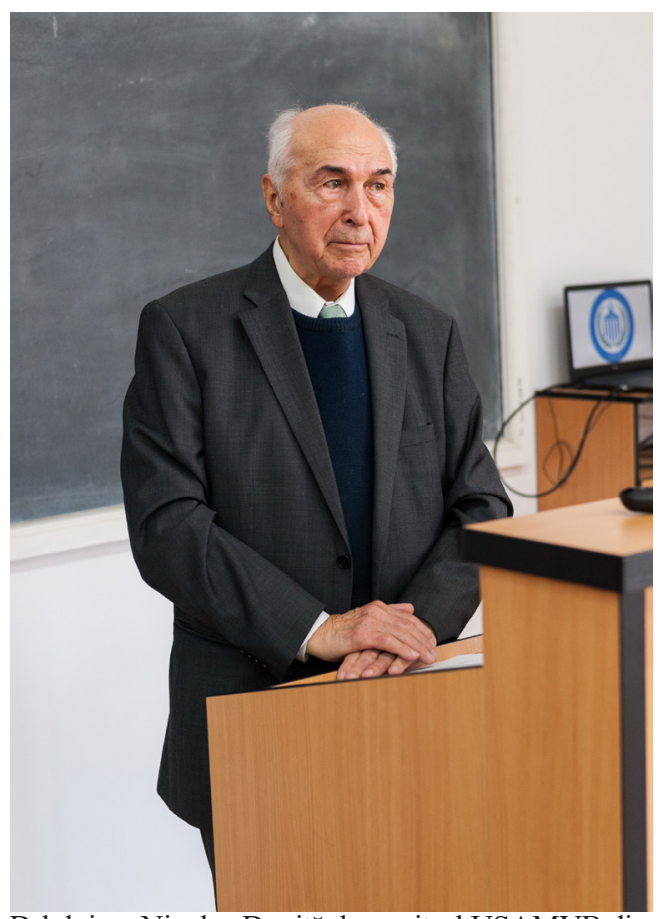

D-1 dr.ing. Nicolae Doniță, la pupitrul USAMVB din Timişoara (Foto: Oliver Mece)

Mr. PhD. eng. Nicolae Doniță at the desk of USAMVB Timişoara

cel Mare, SCDEP Câmpulung Moldovenesc a INCDS ,Marin Drăcea”), Oradea (Universitatea din Oradea), Arad (Universitatea Vasile Goldiș), București (Institutul de Biologie al Academiei Române, Universitatea din București, Universitatea Ecologică, USAMV București), precum și din unități ale administrației silvice și ale ariilor naturale protejate.

La ceremonia de deschidere au participat: d-1 prof.dr.ing. Cosmin Alin Popescu, rector al USAMVB „Regele Mihai I al României”, d-1 


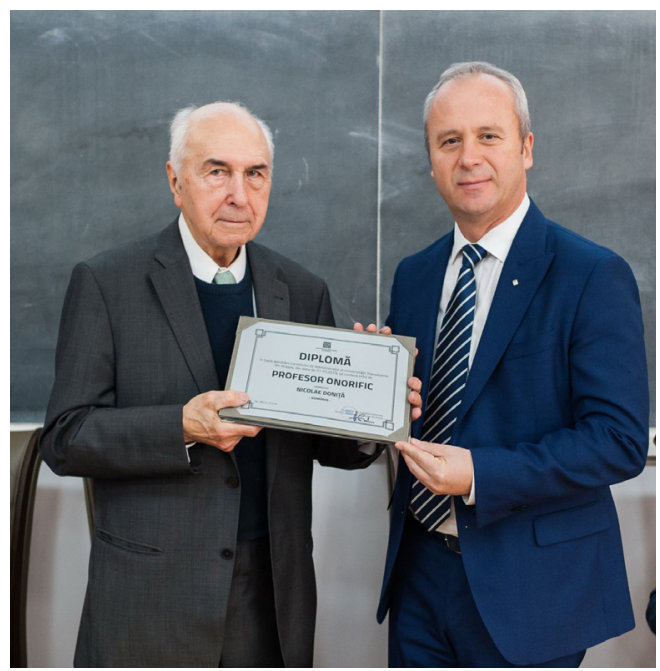

Momentul primirii diplomei de profesor invitat al Universității Transilvania (Foto: Oliver Merce)

Moment of conferring the guest professor title of Transilvania University

prof.dr.ing. Ioan Vasile Abrudan, rector al Universităţii Transilvania, alături de reprezentanţi ai Universității Babeș-Bolyai din Cluj-Napoca, Universităţii din Camerino (Italia), Universității din Oradea, Universității Ștefan cel Mare din Suceava, Societății Progresul Silvic, care au evocat personalitatea d-lui dr. Nicolae Doniță și i-au decernat diplome omagiale din partea instituțiilor pe care le reprezintă.

Domnul rector Ioan-Vasile Abrudan, în numele prestigioasei universități pe care o conduce, i-a decernat sărbătoritului nu doar o diplomă omagială ci și statutul de profesor invitat, pe viață. Conferința a fost generoasă din punct de vedere știinţific: zece comunicări, urmate de întrebări, și două postere. Tematica a acoperit aspecte referitoare la habitatele forestiere, din perspectiva celui de-al doilea raport înaintat Comisiei Europene, monoculturile forestiere din zonele tropicale și subtropicale, pădurile seculare și tipurile de ecosisteme din zona forestieră de câmpie.

Cele patru comunicări prezentate la sesiunea de comunicări științifice de la ASAS s-au axat asupra relațiilor dintre populație, biocenoză și ecosistem, în dorinţa de a integra, într-o viziune praxiologică, cele trei concepte teoretice.

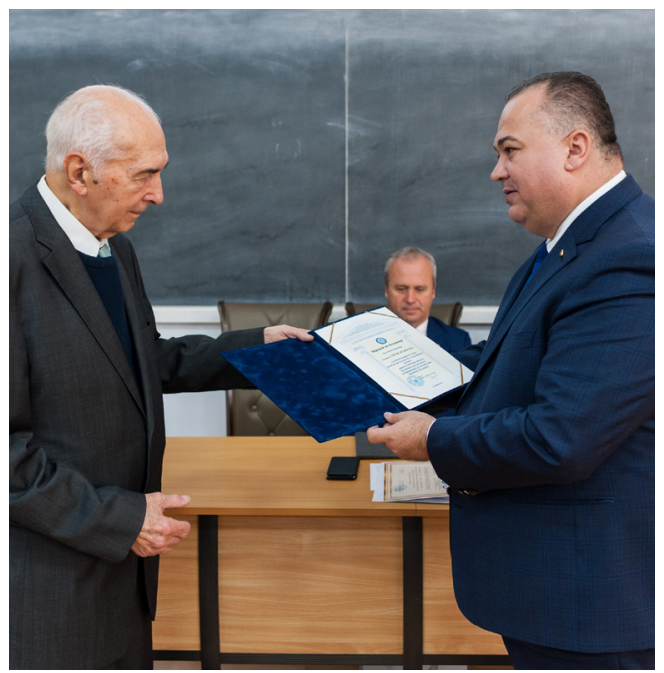

Momentul primirii diplomei omagiale conferite de USAMVB din Timişoara (Foto: Oliver Merce) Moment of conferring the honorary diploma from USAMVB Timisoara

Peste timp, domnia sa a încheiat un cerc, deschis în 2011, când a predat o lectio magistralis despre rolul geografiei în formarea unei viziuni ecologice asupra modului de funcţionare și gestionare a ecosistemelor terestre (cu ocazia decernării titlului de doctor Honoris Causa al Universității „Ștefan cel Mare” din Suceava).

Conferința a fost deschisă de sărbătorit, cu o comunicare ce a abordat relaţia ecologie silvicultură din punct de vedere epistemologic. A doua prezentare, a subsemnatului, a vizat fundamentarea soluțiilor amenajistice pe baze ecologice, în care am reluat o serie de detalii tehnice, prezentate în cursul de amenajare a pădurilor, publicat în 2004, referitoare la modul de interpretare a informaţiilor oferite de schema ecologică, pe baza căreia se propun soluțiile tehnice de conducere și regenerare a arboretelor. Cum dinamica populațiilor de insecte este foarte activă, mai ales în contextul climatic actual, acest subiect nu putea lipsi în agenda manifestării științifice organizate la București (dr.ing. Nicolae Olenici: „Populația de insecte, ca unitate ecologică de lucru în protecția populațiilor de arbori’"). În sfârșit, ultima prezentare (a d-lui profesor dr.ing. Ion Florescu), a tratat populația de arbori, ca unitate 


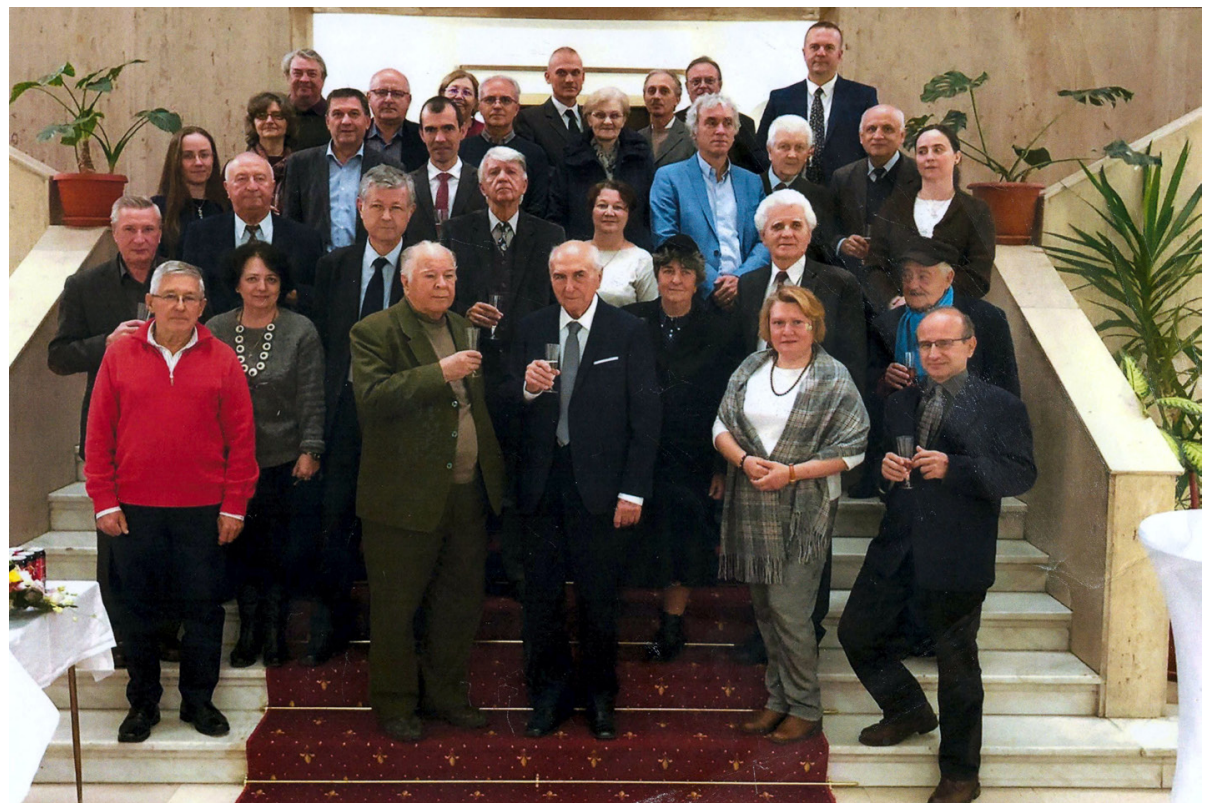

Participanții la Conferința omagială de la Academia de Științe Agricole și Silvice „Gheorghe Ionescu-Șișești” din 22.11.2019 (Foto: Oliver Mece)

Participants at homage conference from Academy of Agricultural and Forestry Sciences "Gheorghe Ionescu-Şişeşti" held in 22.11.2019

ecologică structurală în conducerea și regenerarea pădurilor.

Domnul dr. Nicolae Doniță a știut, de-a lungul frumoasei și impresionantei cariere, să se poziționeze, din punct de vedere științific, la răscruci, dar nu ale unor drumuri bătătorite de alții, ci ale unor drumuri ce urmau a fi deschise. Și nu a fost niciodată singur; a avut alături o minunată soție, pe d-na Doina Ivan, ce îi veghează de acolo, din Ceruri, dragostea cu care îl vom înconjura aici, pe Pământ, cât timp ne va fi dat și nouă să simțim, fiecare în felul lui, căldura și bogăția unei nișe sociale.

Toți cei care am avut onoarea și plăcerea să îl cunoaștem și să colaborăm cu dânsul, îi mulțumim că ne-a oferit prilejul să îl reîntâlnim la ceas aniversar, să ne revedem între noi, „urmaşii” dânsului, care în prezent lucrăm în universități, institute și staţiuni de cercetare, muzee de științe naturale răspândite pe tot cuprinsul țării, și să îi mărturisim dragostea, respectul și prețuirea pe care i-o purtăm. Ne dorim să ne mai ofere această ocazie şi peste 10 ani, la împlinirea vârstei de 100 de ani.
La mulți ani cu sănătate domnule Profesor!

Marian Drăgoi

\section{Abstract. Anniversary moment: PhD, Nicolae Do-} nita

On November 22, 2019 the Romanian forestry celebrated the 90th anniversary of doctor Nicole Doniță, a leading scientist to whom we owe the Romanian typology of forest ecosystems. This celebration was a good opportunity for the academic for a to organize two conferences, one held by the University of Agriculture and Veterinary Medicine of Timisoara (November 15) and the other one held by the Academy of Agriculture and Forestry Sciences „Gheorghe Ionescu-Şișești”, one week later (November, 22). The first conference galvanized many scientists through Romania who defended ten different papers focused on different aspects of applied forest ecology, while the second one was more demanding in terms of scientific standards: only four papers were allowed and their topics were strictly related to population, biocenoses and ecosystems.

Author. Marian Drăgoi - Ștefan cel Mare University of Suceava, Faculty of Forestry, 13 Universității, 720229 Suceava, Romania. 